\title{
GCU
}

Glasgow Caledonian

University

University for the Common Good

\section{An observational cross-sectional study on the corneal endothelium of medium-term rigid gas permeable contact lens wearers}

Doughty, Michael

Published in:

Contact Lens and Anterior Eye

DOI:

10.1016/j.clae.2016.12.001

Publication date:

2017

Document Version

Author accepted manuscript

Link to publication in ResearchOnline

Citation for published version (Harvard):

Doughty, M 2017, 'An observational cross-sectional study on the corneal endothelium of medium-term rigid gas permeable contact lens wearers', Contact Lens and Anterior Eye, vol. 40, no. 2, pp. 109-115.

https://doi.org/10.1016/j.clae.2016.12.001

\section{General rights}

Copyright and moral rights for the publications made accessible in the public portal are retained by the authors and/or other copyright owners and it is a condition of accessing publications that users recognise and abide by the legal requirements associated with these rights.

Take down policy

If you believe that this document breaches copyright please view our takedown policy at https://edshare.gcu.ac.uk/id/eprint/5179 for details

of how to contact us. 


\section{An observational cross-sectional study on the corneal endothelium of medium-term rigid gas permeable contact lens wearers}

Michael J. Doughty, PhD

Glasgow-Caledonian University, Department of Vision Sciences, Cowcaddens Road, Glasgow

G4 OBA e-mail: m.doughty@gcal.ac.uk

\section{ABSTRACT 249}

Purpose: To assess if polymegethism and pleomorphism were evident in corneal endothelium after medium-term rigid gas permeable (RGP) contact lens wear.

Methods: In a cross-sectional observational study over 12 years, single images of the central region of the corneal endothelium of one eye of 46 subjects were taken with a non-contact specular microscope, along with a measure of central corneal thickness (CCT). The images were printed onto A3-sized paper and 100 cells/ image measured by planimetry.

Results: Subjects aged between 20 and 32 years, with an average cumulative RGP wear of 6.0 +/- 1.6 years (range 3 to 9 years) were assessed; 26 of the subjects were Caucasian and 20 were Asian. The mean CCT was $0.515+/-0.027 \mathrm{~mm}$. The group cell area value was $401+/-42 \mathrm{sq}$ micron to give an estimated endothelial cell density (ECD) of $2520+/-273$ cells / sq mm. As compared to a historical database, most endothelia (37/46) showed some changes with the mean coefficient of variation on cell area (COV) being $36.7+/-8.0 \%$ and the percentage of 6 -sided (HEX) being $51.8+/-8.8 \%$. There were modest correlations between years of RGP wear and both $\operatorname{COV}(\mathrm{p}=0.009, \mathrm{r}$ spearman $=0.424)$ and $\operatorname{HEX}(\mathrm{p}=0.025, \mathrm{r}$ spearman $=-0.291)$, but not for ECD or CCT.

Conclusions: Corneal endothelial polymegethism appears to be a commonplace consequence of RGP lens wear with the magnitude of the change being related to the cumulative duration of the lens wear.

Key words: human, corneal endothelium, RGP lens wear, polymegethism, cell pleomorphism

The author has no funding or conflicts of interest to disclose 


\section{[INTRODUCTION]}

As viewed in vivo by specular microscopy, the corneal endothelium of the young healthy adult appears remarkable in being composed of cells with uniformity in size and shape [1,2]. The cell size, as reported in the vast majority of endothelial assessments, is given as the endothelial cell density, or ECD, in cells $/ \mathrm{mm}^{2}$. The uniformity of the cell mosaic is less commonly assessed, but where undertaken has been described by calculations of the coefficient of variation in cell area (usually referred to as the $\mathrm{COV}, \mathrm{CV}$ or polymegethism index) and the relative numbers of 6-sided cells (usually referred to as the hexagonality or HEX measure) [3]. For healthy young adults (e.g. aged between 20 and 40 years of age) who were not contact lens wearers but of different ethnic groups, early publications on endothelial morphometry over nearly a 20 year period indicated that the COV values would likely be between 25 and $30 \%$ and the percentage of 6-sided cells between 60 and $70 \%$ [4-14]. Such reports provided a basis for a recognition, over the same time period, that such an apparently uniform mosaic was not always evident.

It was long ago recognized that contact lens wear could result in the development of remarkable non-uniformity to the endothelial mosaic, with the appearance of substantial polymegethism (increased variation in cell areas) and pleomorphism (reduced percentage of 6sided cells) [15]; this was evident if polymethylmethacrylate (PMMA) lenses were worn with effect being attributed to the very limited oxygen permeability of these lenses. With the advent of contact lens materials with higher oxygen permeability (e.g. rigid gas permeable, RGP lenses) it might be expected that long-term lens-wear-associated polymegethism of the corneal endothelium would be less or not even evident.

In early years of assessments of RGP lens wear and the corneal endothelium, a number of small scale studies (less than 20 eyes), and mostly after only 1 year of RGP lens wear concluded that substantial polymegethism was not evident [14,16--21]. However, one prospective study did report that while the average COV after 1 year of RGP lens wear (without prior contact lens wear) was only $31 \%$, COV values as high as $40 \%$ could be seen in some individuals [16]. Similarly, another prospective study of 13 to 19 subjects over 3 years indicated that there was a progressive increase in COV to an average of $31 \pm 6 \%$ [14]. However, a more recent report from two USA sites, that included data from a cross-sectional analysis of the endothelia (by non-contact specular microscopy) of subjects recruited into a continuous wear trial [22], noted a prior history of RGP lens wear averaging 19.7 \pm 9.7 years and that these 21 subjects had an average COV of $40.14 \pm 7.04 \%$ (mean \pm SD), i.e. indicating that most of the RGP lens wearers had COV values above $30 \%$. Some other endothelial studies have been undertaken on RGP lens wearers but have not reported on the COV.

Based on the published studies, there is a lack of information on the corneal endothelium after medium-term wear of RGP contact lenses. With the more recent report indicating rather high average COV values in longer-term RGP lens wearers [Barr et al., 2003], assessments were started of the endothelia of medium-term RGP lens wearers. These assessments were undertaken over a 12 year as opportunities arose as part of ongoing studies on the human corneal endothelium period. The same imaging capture system (non contact specular microscopy) and image analysis method (pictures enlarged, borders marked and the same number of cells assessed) was used throughout.

\section{SUBJECTS AND METHODS}

\section{Subjects and RGP lens wear details}

With approval from the university ethics committee, the subjects were recruited on an ad hoc basis over a 12 year period by personal contact with undergraduate and especially graduate student classes who were asked if anyone was an RGP lens wearer and would mind having their cornea assessed by the author. Subjects were advised that the image acquisitions would be 
anonymous, and provided written consent. The Glasgow-Caledonian University Ocular Comfort Questionnaire [23] was completed by almost all subjects (41 of 46), and included a blank visual analogue scale (VAS) where the subjects were asked to indicate their comfort from 'Uncomfortable' to 'Comfortable' with a vertical line. The distance on a 100 point scale (not included) was then measured. The questionnaire also included questions on gender, ethnic origin and the students self-reported refractive error, years of RGP contact lens wear (with a check made that no soft contact lenses had been used and that no refractive surgery had been undertaken) and medicines use. Depending on time available and interest from the students, the investigator also tried to obtain information on the actual lens being worn but this generally proved to be rather unproductive as a history of more than one RGP lens type was reported by many of the subjects (see results).

\section{Endothelial image acquisition}

Single images of the central region of the corneal endothelium were used from one eye of each subject. These images were mostly taken with the Topcon SP-3000P instrument, but a few earlier subjects were evaluated using the previous SP-2000P model, with both instruments being used in auto-focus mode and having the same internal calibration scale. In both cases, the specular microscope was linked to a thermal paper printer (Sony Videographic Printer, model UP-897) which was also routinely used to capture an image of the external eye. As the image, especially the eyelid margins, was brought into focus using the joystick control, the printer was manually activated and produced a reasonable resolution photograph of the external eye at a nominal 4X magnification (Figure 1). This was principally used to judge whether or not the horizontal corneal diameter (HCD) was within normal limits [24], but also provides a gross assessment of external eye appearance. This included whether or not any obvious hyperaemia (injection) of the bulbar conjunctiva was evident, the uniformity of the lower tear meniscus, how much reflective material (principally meibum) was present across the lower eyelid marginal zone and also (especially for female subjects) the state of the eyelashes (including how much make up was present). This viewing perspective (as shown in Figure 1) also allowed for gross assessment of how clean the surface of the contact lens was (especially in the women), and of how mobile the lens was. Taking this first image took quite a bit of patience since the subtle movement of the lens is likely detected by the auto-focus mechanism and the image acquisition (of the endothelium) often took several seconds of careful control of image focussing. This first image, when the auto-focus for the endothelium is activated, also provided pachymetry output of the central corneal region with the RGP lens in place. The subjects were then asked to take their contact lens out and another image of the central region of the endothelium captured. This was usually and easily accomplished at the first attempt and provided an image of numerous cells in clear focus, with a pachymetry output for the cornea without the RGP lens in place.

\section{Image processing}

All image processing was undertaken by the author. After attaching a number code ID to the prints, these were assessed by manual cell border marking and planimetry essentially as previously detailed [24]. 100 cells / image were marked (see Figures 2 to 4) and their areas measured to within an estimated $\pm 2 \%$ accuracy or better. The number of 6-sided cells (HEX) was also counted.

\section{Statistical analyses}

Using Systat (v. 11, Systat, IL), the average cell area value (in $\mu \mathrm{m}^{2}$ ), the SD and the coefficient of variation ( $\mathrm{COV}$, based on $\mathrm{SD} /$ average cell area) were calculated, as was an estimate of the 
endothelial cell density (ECD) based on 1000000/ average cell area value. Individual data from each image were then used to calculate global mean values for the set of subjects. Comparisons between output measures were generally made using a Spearman rank order correlation $\left(r_{s}\right)$, but some continuous regression analyses were also undertaken to assess possible inter-dependency of the outcome measures.

\section{RESULTS}

\section{Subject characteristics}

The 46 RGP lens wearing subjects, 31 being male, were aged between 20 and 32 years (average $26.0 \pm 2.4 \mathrm{y}$ ), in good general health, and were from different ethnic groups, being identified as white Northern European (14), white Southern European (6), from Pakistan (4), SriLanka (1), mainland China (7), Hong Kong (3), Tawian (2), and Malaysia (3). Overall, these were grouped into Caucasian (26) and Asian (20). There were many different lens types, as worn at the time of presentation, and most subjects reported either a recent change in lens type or that they had tried several lenses. Notwithstanding, the reported lens products included Boston 2, Boston 4 (IV), Boston XO2, Comfort HO, Aquila Comfort, Menicon EX, Menicon Z, Alpha1, Quantum 2, Fluoroperm 30 and 90, Icon Ultra, Metro O2, Paraperm O2 and 02 Plus, i.e. probably including the whole range of RGP lens $D_{k}$ values from 30 to 160. Lens thickness data was not collected simply because most subjects had no idea of what this was (although attempts were made to measure these, see below). All the subjects were myopes (average refractive error of $3.875 \pm-1.166 \mathrm{DS}$, range -2.50 to $-7.50 \mathrm{DS}$ ), and reported an average period of $6.0 \pm 1.7$ years of RGP lens wear (range 3 to 9 years, median 6.0 years).

All subjects indicated that they wore their contact lenses most days, and usually on a daily-wear routine (i.e. with overnight cleaning and disinfection). Only 7 subjects insisted that they wore their contact lenses every day, with most subjects reporting having spectacles for wearing on some days especially if their lenses were uncomfortable for some reason. If comfortable, then lens wear was generally for the whole day. Just 6 subjects admitted having tried extended wear (up to a week) or continuous wear (up to 30 days) for periods of just a few months when trying another lens before returning (usually) to daily wear. No subject indicated any serious contact lens wear-related adverse events (infection, severe red eye etc). The average comfort score, at the time of presentation, was $79 \pm 12$ (on a scale of 100, range 58 to 98), with some subjects obviously tolerating their contact lens wear despite their eyes not feeling very comfortable yet others reporting being remarkably comfortable with their RGP lens wear. There was no overall difference in average age (26.1 vs. 25.8 years, Caucasian versus Asian), refractive error (-3.798 vs. - 3.975 DS), or lens wear experience (average 5.9 vs. 6.1 years) between the two ethnic groupings.

External eye evaluations (Figure 1) did not indicate any substantial redness or any other abnormalities of the bulbar conjunctiva, any substantial eyelid margin problems (with uniform or reasonably uniform inferior tear meniscus), or significant Meibomian gland dysfunction (MGD), although in a few cases (7) the eyelid margins were considered to have significant amounts of meibum present on them. These gross external eye assessments indicated a normal palpebral aperture with no obvious signs of RGP lens wear-related ptosis. Five of the male subjects had substantial amorphous deposits on their lens surfaces (i.e. notable lens surface spoilage), and nearly half the female subjects had obvious traces of cosmetics on their lens surfaces.

At least some lens mobility was present in all subjects, an aspect fairly readily assessed based on two aspects of taking the external eye image (Figure 1). With a lens in place, it can take quite a few seconds to correctly align the specular microsope even with auto-focus mode because of slight movement of the lens. Secondly, in many cases, as the external eye image was 
brought into focus a slight downward movement and temporary decentration of a freely moving lens was very evident. An image was then taken, if possible, of the corneal endothelium with the instrument then generating a thickness $(\mathrm{T})$ value with the contact lens in place. The subjects were then asked to remove their contact lenses to allow a better view of the corneal

endothelium. The instrument now generated a thickness value of just the cornea. In 29 subjects so evaluated, the difference in the $\mathrm{T}$ values with a contact lens in place and after removal, was between 0.127 and $0.245 \mathrm{~mm}$, indicating RGP contact lens thickness values averaging 0.193 $\mathrm{mm}$, i.e. unremarkable. Such values are perhaps overestimated by the presence of the post-lens tear film. The central corneal thickness values ranged from 0.466 to $0.559 \mathrm{~mm}$ (average \pm SD $0.515 \pm 0.027 \mathrm{~mm}$, median $0.516 \mathrm{~mm}$ ). Central corneal thickness values, as taken immediately after lens removal, were marginally lower in the Caucasians $(0.512$ vs. $0.519 \mathrm{~mm})$ but this was not statistically different $(\mathrm{p}>0.5)$.

\section{Endothelial morphology}

All images showed a high number of clearly-defined cells with no signs of blebs or guttae. An example of a non-contact lens-wearing subject of the same age as the study group is shown for comparison in Figure 2, while the endothelia of two RGP wearers are shown in Figures 3 and 4. The cell outlining procedures are shown in Figures 2B, 3B and 4B, a process which serves to highlight where there are obvious irregularities in the endothelial mosaic.

A reference example (Figure 2) shows an unremarkable (homogeneous, uniform) endothelial mosaic with most cells being of a similar size. The estimated ECD was 2947 cells / $\mathrm{mm}^{2}$ and COV was $26.9 \%$. A few images from the RGP lens wearers were also unremarkable (i.e. showing a largely uniform cell morphology similar to that shown in Figure 2), but most showed signs of slight (e.g. Figure 3) or modest (see Figure 4) polymegethism and plemorphism. In the first RGP example (Figure 3), representative of the overall results obtained, a fairly substantial proportion of the marked cells are of similar size although there are clearly a few somewhat larger cells; the latter are the principal cause of the calculated increase in COV. The image shown in Figure 3 had an estimated ECD of 2732 cells $/ \mathrm{mm}^{2}$ and a COV of $37.7 \%$. In the more substantially altered second example from an RGP lens wearer (Figure 4), the marked cells include not only a number of much larger ones (with 8 or even 9 sides), but there are also a notable number of smaller (4- or 5-sided) cells. The reduced cell density in Figure 3 is hopefully obvious, with an estimated ECD of 2201 cells $/ \mathrm{mm}^{2}$. The COV, with the combination of larger and smaller cells present, was $57.8 \%$.

\section{Endothelial morphometry}

The average cell area values ranged from 310 to $495 \mu \mathrm{m}^{2}$ for a group mean across the 46 subjects of $401 \pm 42 \mu \mathrm{m}^{2}$ (median $402 \mu \mathrm{m}^{2}$ ). If these average values are used to calculate an ECD estimate, these values ranged from 2020 to 3226 cells $/ \mathrm{mm}^{2}$ (group mean $2520 \pm 273$ cells $/ \mathrm{mm}^{2}$, median 2491 cells $/ \mathrm{mm}^{2}$ ). Most endothelia showed signs of polymegethism with only 9/ 46 (19.6\%) having COV values less than $30 \%$. The group mean COV for the 46 corneas was $36.7 \pm 8.0 \%$ (median $35.7 \%$ ), and the percentage of 6 -sided cells (HEX) had a group mean value of $51.8 \pm 8.8 \%$.

Overall, there was no obvious correlation between average area and $\operatorname{COV}\left(\mathrm{r}_{\mathrm{s}}=0.023\right)$ or ECD and COV $\left(r_{s}=-0.022\right)$, but there were a few subjects (8) with rather different (higher) COV values ( $>40 \%$ ) and larger cells areas. Only 3 of these subjects admitted to having tried extended or continuous wear lenses (so these unusual endothelial appearances cannot be obviously attributed to a substantially different lens wear routine, see discussion). However, 6 of them (including 2 of those with some previous continuous wear) had notable spoilage of their contact lens surface and 5 of them reported wearing their lenses every day on a routine 
basis. Five other subjects with notable lens spoilage had COV values between 30 and $40 \%$, but all of these reported lens wear only on most days. The notable changes in endothelia might thus be linked to non-optimal lens hygiene with a build up of inflammatory mediators (see discussion).

There were slight differences in the endothelial morphometry when comparing the Caucasian and Asian subjects, but none reached statistical significance. The average area values were $411 \pm 38 \mu \mathrm{m}^{2}$ for Caucasians and $389 \pm 47 \mu \mathrm{m}^{2}$ for the Asians $(\mathrm{p}=0.078)$ with the net result that the estimated ECD values were lower in the Caucasians (at $2455 \pm 227$ versus 2604 \pm 308 cells $/ \mathrm{mm}^{2} ; \mathrm{p}=0.080$ ). The COV values were slightly higher in the Asian subjects $(38.8 \pm 8.8 \%$ versus $35.0 \pm 6.9 \% ; p=0.132)$ and the percentage of 6 -sided cells was slightly lower in the Asians (49.5 $\pm 7.1 \%$ versus $53.7 \pm 9.6 \%, \mathrm{p}=0.087)$.

Overall, using simple linear models or Spearman correlations, the extent of the polymegethism appeared to be predictably linked to the years of the RGP lens wear (Figure 4A, $\left.\mathrm{p}=0.009, \mathrm{r}_{\mathrm{s}}=0.424\right)$, but there was no obvious functional consequence with CCT showing no relationship to years of lens wear $\left(p=0.269, r_{s}=0.166\right)$ nor to the average COV $\left(p=0.121, r_{s}=\right.$ $0.181)$. Age, per se, was not a predictor of the COV as based on simple linear modelling $\left(\mathrm{r}_{\mathrm{s}}=\right.$ 0.031) or multivariant modelling (unpublished analyses). Similarly, there was no obvious relationship between the CCT value and the RGP lens thickness $\left(\mathrm{r}_{\mathrm{s}}=0.087\right)$ or the lens thickness at the time of assessment and the $\operatorname{COV}\left(r_{s}=0.102\right)$. However, the COV change was accompanied by a predictable reduction in the percentage of 6 -sided cells (Figure 4B, $p=$ $0.025, r_{s}=-0.291$ ), i.e. the higher the COV the smaller the percentage of 6-sided cells (HEX). The observed polymegethism showed no relationship to the subject's reported comfort $\left(\mathrm{r}_{\mathrm{s}}=\right.$ $0.014)$.

\section{DISCUSSION}

This report provides detailed objective analysis of the corneal endothelia of young adults after medium-term RGP lens wear, and also illustrations of the appearance of the altered endothelia (which have not been included in previous reports). It is readily acknowledged that this present study is limited in neither having data before as well as after a strictly-designated period of RGP lens wear for known number of hours / day, nor having the same lens type over the period of assessment etc.

The results from this observational cross-sectional study are presented as a realistic perspective on what might be encountered in RGP lens wearers after medium-term (6 years) of fairly regular RGP lens wear. The assessments in the present study were made simply as opportunities arose, with there being relatively few contact lens wearers encountered who had chosen the RGP option. Most of the students were enrolled in vision science teaching programs and so were familiar with other assessments of their contact wear, even if overseas students, and were relied upon to provide reasonable information on their lens wear history, lens type(s) and refractive error. The study is limited by being selective in that only those wishing to have an assessment made were included, and there was no standardization of constancy in lens type, lens wear routines, lens care systems, etc., all of which likely changed over the long period of the data collection (although the same criticism can surely also be made of the only other longer-term study reporting on endothelial COV in RGP lens wearers [22]).

As indicated in the introduction, from a perspective that the introduction of RGP lenses would result in much lower endothelial polymegethism compared to PMMA lens wear, the early evidence presented to support such an expectation does not appear to be substantial [1621], although there was relatively little data available at that time on how fast (or slowly) polymegethism might develop. Notwithstanding, from this perspective it is perhaps surprising that the more recent report indicated that average COV values of close to $40 \%$ could be present 
after longer term RGP lens wear and so some would have even higher COV values [22]. This more recent study does not include any details of clinical assessments, lenses or lens wear of the long term RGP lens wearers nor of the morphometry undertaken. The strength of the present report is that a standardized endothelial morphometric procedure was used (which can be can be considered as essentially free of the random errors that can so readily occur with softwarebased automated morphometry) and also provides some more clinical details.

The overall result is that corneal endothelial polymegethism can be evident in longerterm RGP lens wearers. Older publications, as well as newer ones, strongly indicate that in normal healthy non contact lens-wearing young adults, a uniform endothelial mosaic should be apparent [4-14,25-28]. More specifically, previously published studies from this laboratory (using essentially the same manual outlining of cells and digitization) have consistently shown that in such individuals, the endothelial cell area variability (COV) was likely to be less than 30 $\%[1,10,24,28]$. Selecting only subjects aged 20 to 32 years from these publications, with similar proportions of white and Asian subjects ( $n=127$ in total), the average ECD was 2785 cells $/ \mathrm{mm}^{2}$, and the percentage 6 -sided cells averaged $64.7 \%$. Most importantly, the average COV was $27.6 \%$, with only 4 subjects $(3.1 \%)$ having COV values that were just slightly higher than $30 \%$. Such uniformity of the endothelia was simply not seen in the majority of the RGP lens wearers evaluated over a 12 year period, and the data analysis indicates that the observed changes are related to the cumulative years of RGP lens wear.

Notwithstanding, the strength of the apparent association between the cumulative duration of RGP lens wear and the changes in the endothelium needs to considered with some caution. An issue that needs to be considered is the reliability (accuracy) of the COV estimates in applying any correlation analyses. Confidence in the projected outcome from a correlation analysis using the COV data for the corneal endothelium is limited because of the inherent uncertainty in the averaged values [29]; this would be expected to be greater when more irregularity (polymegethism) was evident. In addition, there is rather marked heterogeneity in the apparent response of the endothelium to the RGP lens wear in that there appear to be two groups in the scatter plot shown in Figure 5A. The endothelial response can be considered from the perspective of the designated oxygen permeability of the lenses and, it is proposed, to other indirect factors related to lens hygiene.

Both the contact lens Dk value and especially its thickness would be expected to determine the availability of oxygen to the cornea and thus (presumably) its effects on corneal thickness and the endothelium [14,30]. The present study is limited both because a wide range of Dk materials were used and the thickness values of the contact lenses were only assessed in some subjects when it was realized, to some surprise, that the specular microscope did generate a thickness $(\mathrm{T})$ value with a contact lens in place. In addition, with eyeblinking considered to play an important role in facilitating oxygen access to the tear film (by reducing the chance of stagnation of the post-lens tear film), the subject's eyeblink responses to the wearing of an RGP contact lens could be very different especially because quite a wide range of ocular comfort scores were reported. Most relevant to the present study, the $\mathrm{Dk} / \mathrm{L}$ will not only be determined by the lens material but presumably how clean the contact lens was in habitual use. There were many different lens types, as worn at the time of presentation, and most subjects reported either a recent change in lens type or that they had tried several lenses (and so these overall details are not considered very informative). Overall, however, the heterogeneity in the apparent endothelial response was present, despite factoring in the effect of years of contact lens wear or even subject age per se, an outcome indicating other factors beyond the specified lens permeability.

Quite a few of those subjects showing endothelial COV values well in excess of $30 \%$ had substantial lens surface deposits and were insistent that they were very regular wearers of 
their contact lenses. The external eye and lens assessments as well as the details of lens wear habits that could be gleaned from the subjects indicate that non-optimum lens hygiene and resultant lens surface spoilage is an issue that needs to be given further consideration as a factor possibly contributing to the development of corneal endothelial polymegethism and pleomorphism. This could be a result of impairment of oxygen transmissibility of the lenses and / or the development of a mild inflammatory response to deposits on the lens surface. Assessments of tear film levels of inflammatory mediators in RGP contact lens wearers have been reported [31-34]. One earlier report with palpebral assessments noted no detectable difference in nitric oxide levels after an average of nearly 3 years of wear [31]. However, three other reports without palpebral assessments indicate possible increases in another type of inflammatory mediator, interleukins, in the tears of RGP lens wearers [32-34]. Further studies on this aspect of RGP lens wear, to include assessments of the endothelium would be useful. Such increases may also be accompanied by a decrease in tear film levels of natural antiinflammatory molecules such as secretoglobulins in RGP lens wearers [35]

A final comment seems appropriate for the apparent endothelial change and its function. In early consideration of the polymegethism associated with PMMA lens wear, the effect was attributed to hypoxia and considered to be an indicator of altered function of the endothelial cells [36]. As seen in specular reflection, the endothelial mosaic appears to be remarkably uniform. It should be noted that the specular microscopy method for observation of the corneal endothelial cells is limited to the apical surface of the cells (adjacent to the aqueous humour) and not of the whole cell. While this approach to viewing the endothelial cells will likely remain for clinical studies, laboratory-based imaging of isolated corneas at much higher magnification has indicated that the apparent geometric uniformity of the cells may not be evident at the posterior surface of the endothelium (adjacent to Desçemet's membrane) [37]. The difference between the cell morphology at the anterior and posterior surfaces has been proposed to be important in determining the net function of the endothelial cell layer [37], although it remains to be established how predictable this difference might be especially if (anterior) polymegethism or pleomorphism were evident at the apical surface.

In conclusion, mild-to-moderate corneal endothelial polymegethism appears to be a commonplace consequence of the medium-term wear of RGP contact lenses, an effect that might seem at odds with the lens classification. The results in the present study confirm and extend those from previous prospective $[14,16]$ and observational cross-sectional studies [22]. Overall, the present studies indicate that further assessments would be useful especially to assess the external eye and palpebral conjunctiva in more detail in long term RGP lens wearers in addition to the corneal endothelium.

\section{ACKNOWLEDGEMENTS}

The author has no proprietary interests in any of the equipment or methods presented, and has no funding or conflicts of interest to disclose.

\section{REFERENCES}

1. M.J. Doughty. Are there geometric determinants of cell area in rabbit and human corneal endothelial cell monolayers ?. Tissue Cell 30(1998) 537-544.

2. M.J. Doughty. Comparative anatomy and physiology of the cornea and conjunctiva. In Ocular Surface (Martin Herran R, Corrales RM, eds). CRC Press - 2012; pp. 32-78.

3. M.J. Doughty. Towards a quantitative analysis of corneal endothelial cell morphology - a review of techniques and their application. Optom. Vis. Sci. 66 (1989) 626-642. 
4. A. Stefansson, O. Müller, R. Sundmacher. Non-contact specular microscopy of the normal corneal endothelium. A statistical evaluation of morphometric parameters. Graefe's Arch. Clin. Exp. Ophthalmol. 218 (1982) 200-205.

5. M. Matsuda, R.W. Yee, H.F. Edelhauser. Comparison of the corneal endothelium in an American and Japanese population. Arch Ophthalmol. 103 (1985) 68-70.

6. R.W. Yee, M. Matsuda, R.O. Schultz, H.F. Edelhause. Changes in the normal corneal endothelial pattern as a function of age. Curr Eye Res. 4 (1985) 671-678.

7. K.H. Carlson, W.M. Bourne, J.W. Mclaren, R.F. Brubaker. Variations on human corneal endothelial cell morphology and permeability to fluorescein with age. Exp. Eye Res. 47 (1988) 27-41.

8. K.A. Polse, R.J. Brand, S.R. Cohen, M. Guillon. Hypoxic effects on corneal morphology and function. Invest. Ophthalmol. Vis. Sci. 31 (1990) 1542-1554.

9. K-S. Kim, S-Y. Park, J-S. Oh. Morphometric analysis of the corneal endothelial cells in normal Koreans [In Korean]. J. Korean Ophthalmol. Soc. 33 (1992) 24-28.

10. M.J. Doughty. Prevalence of 'non-hexagonal' cells in the corneal endothelium of young Caucasian adults, and their inter-relationships. Ophthal. Physiol. Opt. 18(1998) 415-422.

11. S.W. Cheung, P. Cho. Endothelial cell analysis using the Topcon SP-1000 non-contact specular microscope and IMAGEnet system. Clin. Exp. Optom. 81 (1998) 1-7.

12. S.W. Cheung, P. Cho. Endothelial cells analysis with the TOPCON specular microscope SP-2000P and IMAGEnet system. Curr. Eye Res. 21 (2000) 788-798.

13. S.H. Tseng, F.K. Chen. Morphological and fluorophotometric analysis of the corneal endothelium after radial keratotomy. Cornea 17 (1998) 471-475.

14. W.M. Bourne, S.B. Holtan, D.O. Hodge. Morphologic changes in corneal endothelial cells during 3 years of fluorocarbon contact lens wear. Cornea 18 (1999) 29-33.

15. S.M. MacRae, M. Matsuda, S. Shellans. Corneal endothelial changes associated with contact lens wear. CLAO J. 15 (1989) 82-87.

16. G. Liberman, R.B. Mandell. Corneal endothelial polymegethism in high-Dk contact lens wearers. International Contact Lens Clinic 15 (1988): 282-284.

17. G.N. Orsborn, J.P. Schoessler. Corneal endothelial polymegethism after the extended wear of rigid gas-permeable contact lenses. Am. J. Optom. Physiol. Opt. 65 (1988) 84-90.

18. H. Shioya, M. Kajita, K. Kobari, H. Yamaguchi, K. Kato. Corneal endothelial cell change in gas-permeable hard contact lens wearers [in Japanese]. J. Jpn. Contact Lens Soc. 33 (1991) 158-161.

19. C.P. Nieuwendaal, J.H.C. Kok, E.A.M. de Moor, J. Oosting, H.W. Venema. Corneal endothelial cell morphology under permanent wear of rigid contact lenses. Int Ophthalmol. 15 (1991) 313-319.

20. K. Ogihara, H. Yamaguchi. Prospective study of corneal endothelial cell changes in the early stages of contact lens wear [in Japanese]. J. Jpn. Contact Lens Soc. 37 (1995) 118-122.

21. Y. Mizutani, S. Mizutani, H. Takahashi, K. Ohara. The effects of contact lenses on the corneal endothelium [In Japanese]. J. Jpn. Contact Lens Soc. 40 (1998) 164-171.

22. J.T. Barr, B. Pall, L.B. Szczotka, G.L. Mitchell, W. Gleason. Corneal endothelial morphology results in the Meinicon Z 30-day continuous-wear contact lens clinical trial. Eye Contact Lens 29 (2003) 14-16.

23. M.J. Doughty, C-A. Lee, S. Ritchie, T. Naase. An assessment of the discomfort associated with the use of rose bengal $1 \%$ eyedrops on the human eye - a comparison with saline $0.9 \%$ and a topical ocular anaesthetic. Ophthal. Physiol. Opt. 27 (2007) 159-167.

24. M.J. Doughty. A prospective analysis of corneal endothelial polymegethism and cell density in young adult Asians. Clin. Exp. Otom. 97 (2014) 256-263. 
25. M.J. Doughty, B.M. Aakre. Further analysis of assessments of the coefficient of variation of corneal endothelial cell areas from specular microscope images. Clin. Exp. Optom. 91 (2008) 438-446.

26. C.J. Giasson, L. Gosselin, A. Masella, P. Forcier. Does endothelial cell density correlate with corneal diameter in a group of young adults ?. Cornea 27 (2008) 640-643.

27. M.J. Doughty, A. Müller, M.L. Zaman. Assessment of the reliability of human corneal endothelial cell-density estimates using a noncontact specular microscope. Cornea 19 (2000) 148-158.

28. M.J. Doughty. Evaluation of possible error sources in corneal endothelial morphometry with a semi-automated non-contact specular microscope. Cornea 32 (2013) 1196-1203.

29. M.J. Doughty, D. Fonn, T. Nguyen. Assessment of the reliability of calculations of the coefficient of variation of normal and poylmegethous corneal endothelium. Optom. Vis. Sci. 70 (1993) 759-770.

30. H.P. Gardner, B.A. Fink, L.G. Mitchell, R.M. Hill. The effects of High-Dk rigid contact lens center thickness, material permeability, and blinking on the oxygen uptake of the human cornea. Optom Vis Sci. 82 (2005) 459-466.

31. S. Karaküçuk, E. Mirza, I. Karaküçuk, A. Akal, M. Er. Nitric oxide levels in tears of patients with mild forms of papillary conjunctivitis induced by rigid gas-permeable contact lenses. CLAO J. 28 (2002) 5-8.

32. P. Kallinkos, P. Morgan, N. Efron. Assessment of stromal keratocytes and tear film inflammatory mediators during extended wear of contact lenses. Cornea 25 (2006) 1-10.

33. I. Lema, J.A. Durán, C. Ruiz, E. Diez-Feijoo, A. Acera, J. Merayo. Inflammatory response to contact lenses in patients with keratoconus compared with myopic subjects. Cornea 27 (2008) 758-763.

34. C.Y. Elgin, G. İskeleli, S. Talaz, S. Akyol. Comparative analysis of tear film levels of inflammatory mediators in contact lens users. Curr. Eye Res. 41 (2015) 441-447.

35. C. Kramann, N. Boehm, K. Lorenz, N. Wehrwein, B.M. Stoffelns, N. Pfeiffer, F.H. Grus. Effect of contact lenses on the protein composition of tear film: a ProteinChip study. Graefes Arch. Clin. Exp. Ophthalmol. 249 (2011) 233-243.

36. C.G. Connor, M.E. Zagrod. Contact lens-induced corneal endothelial polymegethism: Functional significance and possible mechanisms. Am. J. Optom. Physiol. Opt. 63 (1986) 639-544.

37. Z. He, F. Forest, P. Gain, D Rageade, A. Bernard, S. Acquart, M. Peoc'h, D. Defoe, G. Thuret. 3D map of the human corneal endothelial cell. Sci Rep. 6 (2016) 29047.

\section{Figure captions}

Figure 1. Example of external eye image captured with SP-3000P specular microscope linked to a thermal printer to show RGP lens in place.

Figure 2. Representative image of central corneal endothelium of a 31 year old male who has never worn contact lenses (A) and the image marking for morphometry (B). The estimated ECD is 2947 cells / $\mathrm{mm}^{2}$ and COV is $26.90 \%$. The scale between the two vertical lines in the box is $200 \mu \mathrm{m}$

Figure 3. Representative image of central corneal endothelium of a 25 year old male with 6 years of fairly regular daily wear of an RGP contact lens (A) and the image marking for morphometry (B). The estimated ECD is 2732 cells $/ \mathrm{mm}^{2}$ and COV is $37.7 \%$, a value very similar to the average from all of the RGP lens wearing subjects. The scale between the two vertical lines in the box is $200 \mu \mathrm{m}$

Figure 4. Image of central corneal endothelium of a 28 year old male with $8 \mathrm{y}$ of largely daily wear of an RGP lens and who had substantial lens spoilage (A) and 
the image marking for morphometry (B). The estimated ECD is 2201 cells / $\mathrm{mm}^{2}$ and the COV is $57.8 \%$. The scale between the two vertical lines in the box is 200 $\mu \mathrm{m}$

Figure 5. Scatterplots to illustrate inter-relationships between the reported number of years of RGP lens wear and endothelial COV (A) and endothelial 6-sided cells percentage (B). 

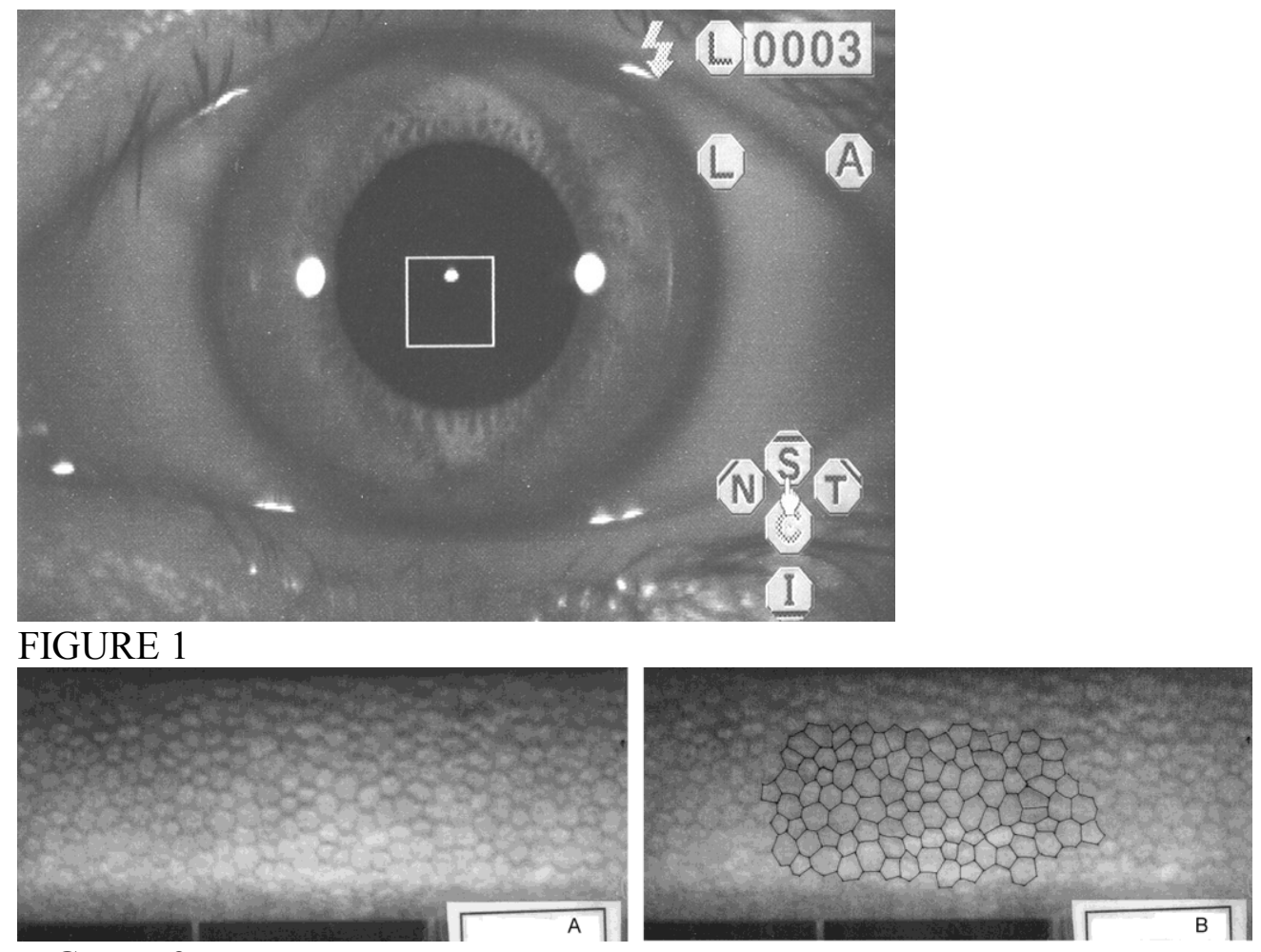

FIGURE 2
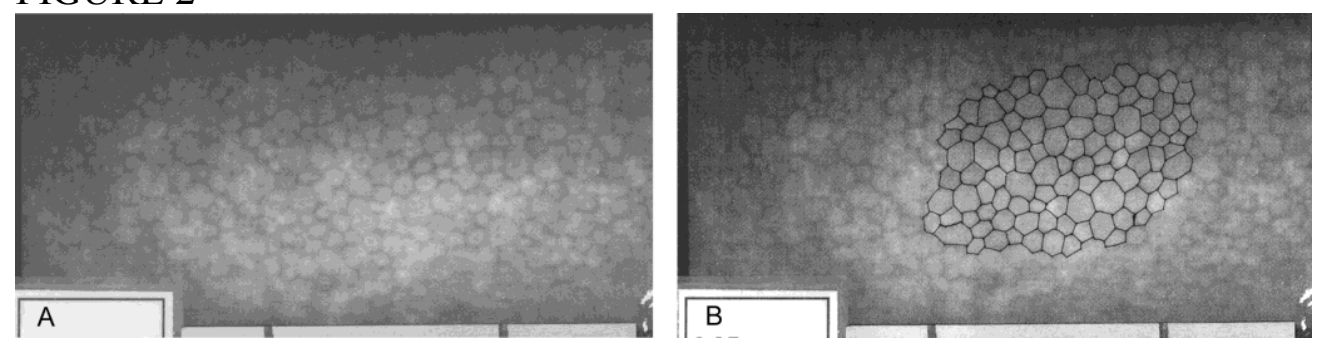

FIGURE 3
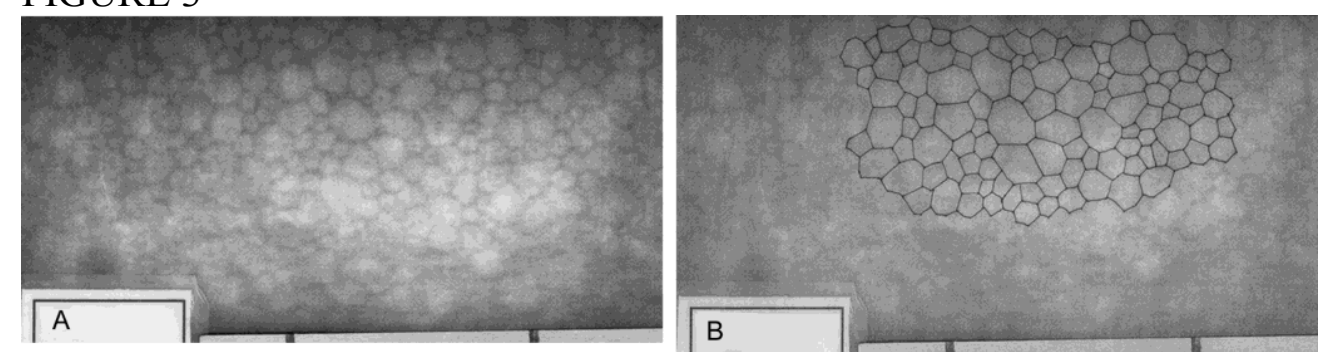

FIGURE 4
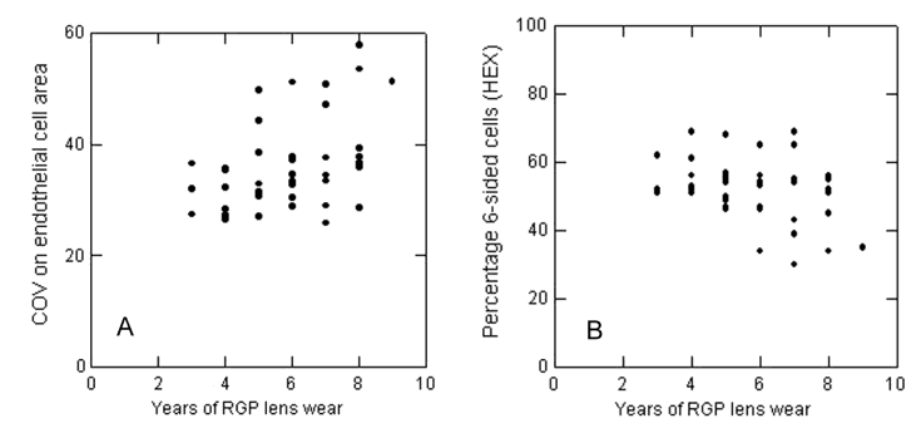

FIGURE 5 